\title{
Bacillus krulwichiae sp. nov., a halotolerant obligate alkaliphile that utilizes benzoate and $m$-hydroxybenzoate
}

\author{
Isao Yumoto, ${ }^{1}$ Shingo Yamaga, ${ }^{1,2}$ Yoko Sogabe, ${ }^{1}$ Yoshinobu Nodasaka, ${ }^{3}$ \\ Hidetoshi Matsuyama, ${ }^{2}$ Kenji Nakajima ${ }^{1}$ and Akio Suemori ${ }^{4}$ \\ ${ }^{1}$ Institute of Biological Resources and Function, Hokkaido Center, National Institute of \\ Advanced Industrial Science and Technology, Tsukisamu-Higashi, Toyohira-ku, Sapporo \\ 062-8517, Japan
${ }^{2}$ Department of Bioscience and Technology, School of Engineering, Hokkaido Tokai University, Minaminosawa, Minami-ku, Sapporo 005-8601, Japan
${ }^{3}$ Laboratory of Electron Microscopy, School of Dentistry, Hokkaido University, Kita-ku, Sapporo 060-8586, Japan
${ }^{4}$ Institute of Biological Resources and Function, Tsukuba Center, National Institute of Advanced Industrial Science and Technology, Higashi 1-1, Tsukuba, Ibaraki 305-8566, Japan

Isao Yumoto

i.yumoto@aist.go.jp

Obligate alkaliphilic strains, $\mathrm{AM} 31 \mathrm{D}^{\top}$ and $\mathrm{AM} 11 \mathrm{D}$, that utilize benzoate and $m$-hydroxybenzoate were isolated from soil obtained from Tsukuba, Ibaraki, Japan. The isolates grew at $\mathrm{pH} 8-10$, but not at neutral $\mathrm{pH}$. They were Gram-positive, facultatively anaerobic, straight rods with peritrichous flagella and produced ellipsoidal spores. The isolates reduced nitrate to nitrite and grew in $0-14 \% \mathrm{NaCl}$, but not in higher concentrations. The major isoprenoid quinones were menaquinone-5, -6 and -7 , and the cellular fatty acid profile consisted of significant amounts of $15-C$ branched-chain acids, iso $\mathrm{C}_{15: 0}$ and anteiso $\mathrm{C}_{15: 0}$. Phylogenetic analysis based on $16 \mathrm{~S}$ rRNA gene sequencing indicated that strain $A M 31 D^{\top}$ was a member of group 6 (alkaliphiles) in the genus Bacillus. DNA-DNA hybridization revealed a low relatedness of the isolates with several phylogenetically close neighbours, including Bacillus alcalophilus and Bacillus pseudalcaliphilus (less than 19.3\%). Based on phenotypic characteristics, phylogenetic data and DNA-DNA relatedness data, it was concluded that these isolates merited classification as a new species, for which the name Bacillus krulwichiae is proposed. The type strain of this species is $A M 31 D^{\top}$ $\left(=\right.$ NCIMB $13904^{\top}=$ JCM $11691^{\top}=$ IAM $\left.15000^{\top}\right)$.

Alkaliphilic Bacillus spp. have been isolated to investigate their physiological adaptation to high $\mathrm{pH}$ and to utilize their enzymes industrially. Although considered to be extremophiles, alkaliphilic Bacillus spp. are distributed not only in unique places such as alkaline soda lakes (Duckworth et al., 1996), but also in ordinary soils and faeces (Horikoshi, 1991). Alkaliphilic bacteria can be either facultative or obligate alkaliphiles (Krulwich \& Guffanti, 1989). Numerous alkaliphilic micro-organisms have been isolated and more than 16 species of alkaliphilic Bacillus spp., including facultative and obligate types, have been identified to date

Published online ahead of print on 21 March 2003 as DOI 10.1099/ ijs.0.02596-0.

Abbreviations: AMBS, alkaline mineral basal salt; SEM, scanning electron microscopy; TEM, transmission electron microscopy.

The GenBank accession number for the $16 \mathrm{~S}$ rRNA sequence of strain $\mathrm{AM} 1 \mathrm{D}^{\top}$ is $\mathrm{AB086897.}$
(Vedder, 1934; Spanka \& Fritze, 1993; Nielsen et al., 1995; Agnew et al., 1995; Fritze, 1996; Switzer Blum et al., 1998; Yumoto et al., 1998).

The microbial degradation of aromatic compounds is important not only for the industrial applications of the respective enzymes involved, but also for studying structural, functional and genetic aspects of aromatic compound oxygenases. However, there is little information concerning alkaliphiles that degrade aromatic compounds, or concerning aromatic compound oxygenases isolated from them. Isolation of aromatic-compound-degrading alkaliphiles might enable the acquisition of new information not only on the taxonomy, physiology and enzymology of alkaliphiles, but also on aromatic compound oxygenases (Gibson \& Subramanian, 1984; Mason \& Cammack, 1992).

In the present study, obligately alkaliphilic micro-organisms that can degrade benzoate and $m$-hydroxybenzoate were 
isolated to study the degradation of aromatic compounds in alkaline environments and the aromatic compound oxygenases that are active at high $\mathrm{pH}$ values. Phenotypic characterization and phylogenetic analysis based on $16 \mathrm{~S}$ rRNA gene sequences showed that the new isolates merited classification as a novel Bacillus species.

Aromatic-compound-contaminated garden soil samples obtained from Tsukuba $\left(36^{\circ} 7^{\prime} \mathrm{N}, 140^{\circ} 13^{\prime} \mathrm{E}\right)$, Ibaraki, Japan, were added to $10 \mathrm{ml}$ alkaline mineral basal salt (AMBS) medium ( $\mathrm{pH} 10)$ containing $0 \cdot 2 \mathrm{~g}$ yeast extract, 3 g hydroxybenzoate, $2.5 \mathrm{~g} \mathrm{NH}_{4} \mathrm{NO}_{3}, 1.5 \mathrm{~g} \mathrm{~K}_{2} \mathrm{HPO}_{4}, 1.5 \mathrm{~g}$ $\mathrm{Na}_{2} \mathrm{HPO}_{4}, 0.5 \mathrm{~g} \mathrm{MgSO}_{4} .7 \mathrm{H}_{2} \mathrm{O}, 10 \mathrm{mg} \mathrm{FeSO} .7 \mathrm{H}_{2} \mathrm{O}, 20 \mathrm{mg}$ $\mathrm{CaCl}_{2} \cdot 2 \mathrm{H}_{2} \mathrm{O}, 1 \mathrm{mg} \mathrm{MnSO}_{4} \cdot n \mathrm{H}_{2} \mathrm{O}, 0.5 \mathrm{mg} \mathrm{ZnSO}_{4} .7 \mathrm{H}_{2} \mathrm{O}$ and $10 \mathrm{~g} \mathrm{Na}_{2} \mathrm{CO}_{3}$ per litre in large tubes $(25 \times 200 \mathrm{~mm})$ and incubated aerobically at $30^{\circ} \mathrm{C}$ for $48 \mathrm{~h}$. Enrichments $(0.5 \mathrm{ml})$ were transferred to fresh medium and cultured for $24 \mathrm{~h}$, then plated onto AMBS agar plates. The isolates were reisolated five times and maintained in PYA (peptone/yeast extract/alkaline) agar medium consisting of $8 \mathrm{~g}$ peptone (Kyokuto), $3 \mathrm{~g}$ yeast extract (Merck), $15 \mathrm{~g}$ agar, $1 \mathrm{~g}$ $\mathrm{K}_{2} \mathrm{HPO}_{4}, 3.5 \mathrm{mg}$ EDTA, $3 \mathrm{mg} \mathrm{ZnSO}_{4} .7 \mathrm{H}_{2} \mathrm{O}, 10 \mathrm{mg}$ $\mathrm{FeSO}_{4} \cdot 7 \mathrm{H}_{2} \mathrm{O}, 2 \mathrm{mg} \mathrm{MnSO}_{4} \cdot n \mathrm{H}_{2} \mathrm{O}, 1 \mathrm{mg} \mathrm{CuSO}_{4} \cdot 5 \mathrm{H}_{2} \mathrm{O}$, $2 \mathrm{mg} \mathrm{Co}\left(\mathrm{NO}_{3}\right)_{2} \cdot 6 \mathrm{H}_{2} \mathrm{O}$ and $1 \mathrm{mg} \mathrm{H}_{3} \mathrm{BO}_{3}$ in $11 \mathrm{NaHCO}_{3} /$ $\mathrm{Na}_{2} \mathrm{CO}_{3}$ buffer (100 mM in deionized water; $\mathrm{pH} 10$ ) at $27^{\circ} \mathrm{C}$. Cells for chemotaxonomic analysis were harvested in the late exponential phase after cultivation with reciprocal shaking (140 r.p.m.) at $27^{\circ} \mathrm{C}$ in PYA medium. In addition to these isolates, Bacillus alcalophilus JCM $5262^{\mathrm{T}}$ and Bacillus pseudalcaliphilus DSM $8725^{\mathrm{T}}$ were used as reference strains for DNA-DNA hybridization. These micro-organisms were cultivated using PYA broth at $27^{\circ} \mathrm{C}$.

For the phenotypic characterization, PYA medium was used as the basal medium. The culture was incubated at $27^{\circ} \mathrm{C}$ for 2 weeks and the experiment was performed more than twice. Acid production from carbohydrate was determined by the method of Hugh \& Leifson (1953) using thymol blue instead of bromothymol blue at $\mathrm{pH} 10$. Growth experiments at $\mathrm{pH}$ 7-10 were performed using PYA media containing $100 \mathrm{mM} \mathrm{NaH}{ }_{2} \mathrm{PO}_{4} / \mathrm{Na}_{2} \mathrm{HPO}_{4}$ buffer (pH 7-8) or $100 \mathrm{mM}$ $\mathrm{NaHCO}_{3} / \mathrm{Na}_{2} \mathrm{CO}_{3}$ buffer (pH 9-10). Anaerobic growth was tested in PYA broth ( $\mathrm{pH} 10$ ) by substituting air with $\mathrm{N}_{2}$ gas. Other physiological and biochemical characteristics were examined according to the methods of Yumoto et al. (1998) and as described in Barrow \& Feltham (1993).

For observation of negatively stained cells by transmission electron microscopy (TEM) and for platinum- and palladium-coated cells by scanning electron microscopy (SEM), cells were grown on a PYA agar slant. The procedure for TEM and SEM preparations and observations were performed as described previously (Yumoto et al., 2002).

Analyses of whole-cell fatty acids and isoprenoid quinones were performed as described previously (Yumoto et al., 2001).

Bacterial DNA was prepared according to the method of Marmur (1961). DNA base composition was determined by the method of Tamaoka \& Komagata (1984). The level of DNA-DNA relatedness was determined fluorometrically by the method of Ezaki et al. (1989) using photobiotin-labelled DNA probes and black microplates.

The 16S rRNA gene sequence corresponding to position 27-1519 in the 16S rRNA gene sequence of Escherichia coli (Brosius et al., 1978) was amplified by PCR. The approximately $1.5 \mathrm{~kb}$ PCR product was sequenced directly by the dideoxynucleotide chain-termination method using a DNA sequencer (PRISM 377; Applied Biosystems). Multiple alignments of the sequence were performed and the nucleotide substitution rate $\left(K_{\text {nuc }}\right)$ was calculated. A phylogenetic tree was constructed by the neighbourjoining method (Kimura, 1980; Saitou \& Nei, 1987) using the CLUSTAL W program (Thompson et al., 1994). Similarity values for sequences were calculated using the GENETYX program (Software Development).

Two strains were isolated on AMBS medium ( $\mathrm{pH} 10$ ). These isolates grew better in AMBS broth containing either $0.3 \%$ $m$-hydroxybenzoate or benzoate than in the same medium devoid of the aromatic compounds. Strain $\mathrm{AM} 31^{\mathrm{T}}$ grew strongly with both $m$-hydroxybenzoate $\left(\mathrm{OD}_{650}=0 \cdot 87\right)$ and benzoate $\left(\mathrm{OD}_{650}=0 \cdot 86\right)$ as the substrate. In contrast, AM11D grew better with benzoate $\left(\mathrm{OD}_{650}=0 \cdot 67\right)$ than with $m$-hydroxybenzoate $\left(\mathrm{OD}_{650}=0 \cdot 32\right)$. These results demonstrated that the two isolates utilized aromatic compounds such as benzoate and $m$-hydroxybenzoate as the substrate. To the best of our knowledge, this is the first observation of alkaliphilic Bacillus strains utilizing aromatic compounds.

Colonies of strain AM31D ${ }^{\mathrm{T}}$ and AM11D on PYA agar were circular and colourless; cells were Gram-positive, peritrichously flagellated rods measuring $0.5-0 \cdot 7 \times 1 \cdot 5-2.6 \mu \mathrm{m}$ (Fig. 1) and produced subterminally located ellipsoidal spores. Spores did not cause swelling of the sporangia.

Physiological and biochemical characteristics of the two isolates are given in the species description below. Growth occurred at a similar level at $\mathrm{pH}$ values from 8 to 10 , but not at $\mathrm{pH}$ 7. The two isolates showed quite similar characteristics. They were facultative anaerobic bacteria, differing only in protease activity. The morphological and phenotypic characteristics suggested that the isolates were obligately alkaliphilic members of the genus Bacillus.

The isoprenoid quinones extracted from isolates using TLC were analysed by HPLC. Analysis revealed that menaquinone-5, -6 and -7 are the major quinones of the isolates. Similar menaquinone contents occur in Bacillus halodurans (Aono, 1995; Takami \& Horikoshi, 1999). The ratio of menaquinone-5/-6/-7 was $1: 11: 27$. GLC analysis revealed that the fatty acids of these strains consisted of iso $\mathrm{C}_{15: 0}$, anteiso $\mathrm{C}_{15: 0}, \mathrm{C}_{16: 1}$, anteiso $\mathrm{C}_{17: 0}$ and anteiso $\mathrm{C}_{17: 1}$. Among these, anteiso $\mathrm{C}_{15: 0}$ was the major component, comprising $45 \cdot 6-49 \cdot 0 \%$ of the total fatty acid content. Results of the analysis of the two isolates are shown in Table 1. Clejan et al. 

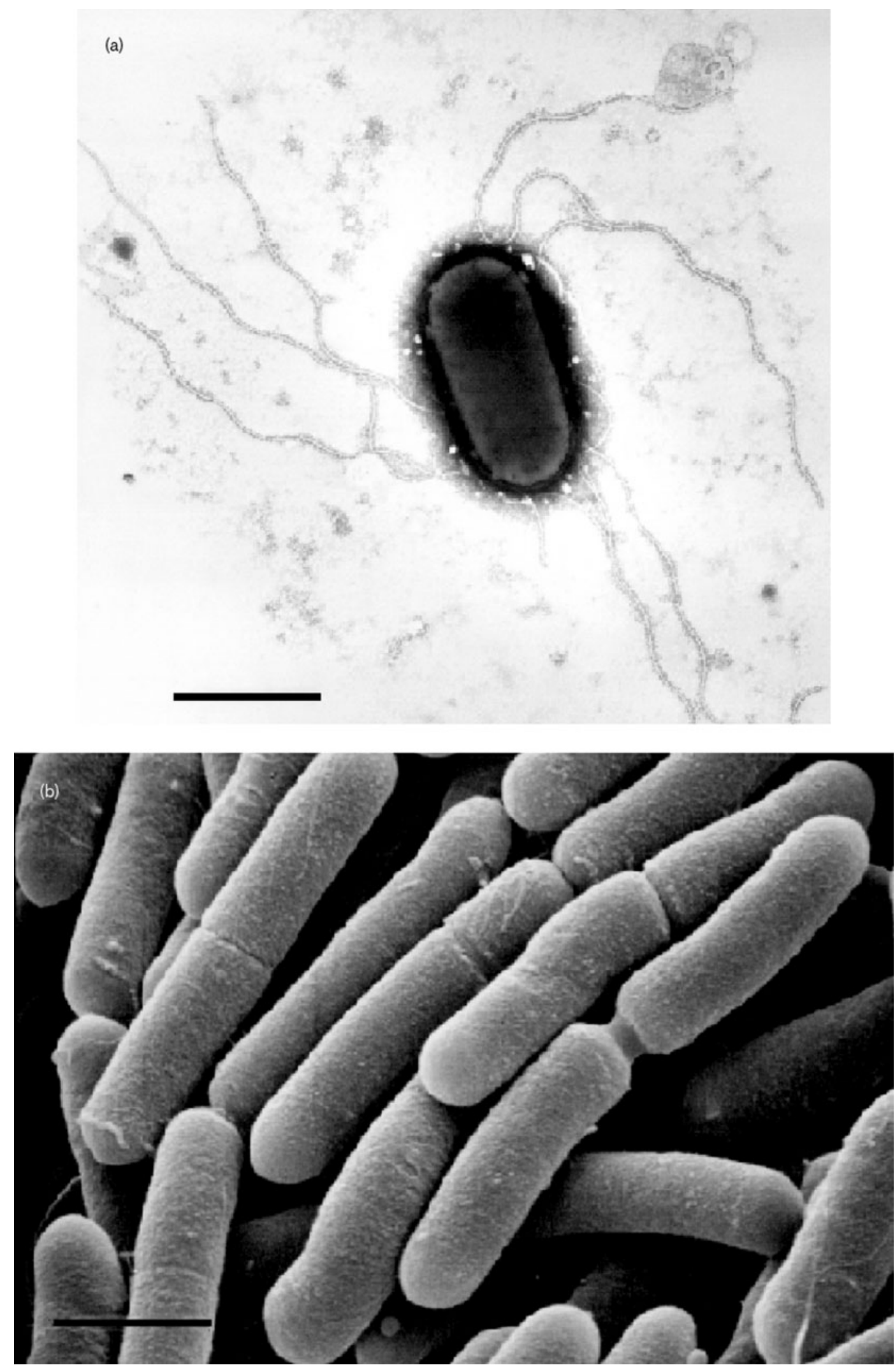

Fig. 1. (a) TEM of a negatively stained cell of Bacillus krulwichiae $A M 31 D^{\top}$, showing peritrichous flagellation. (b) SEM of platinum/palladium-coated Bacillus krulwichiae $\mathrm{AM} 1 \mathrm{D}^{\top}$ cells, showing slightly rough cell surface aspect. Bars, $1 \mu \mathrm{m}$. 
Table 1. Fatty acid composition of Bacillus krulwichiae $A M 31 D^{\top}$ and $A M 11 D$, other alkaliphiles and Bacillus subtilis

1, Bacillus krulwichiae $\mathrm{AM} 1 \mathrm{D}^{\mathrm{T}}$; 2, Bacillus krulwichiae AM11D;

3, Bacillus cohnii DSM $6307^{\mathrm{T}}$; 4, Bacillus alcalophilus JCM $5262^{\mathrm{T}}$;

5, Bacillus subtilis IAM 1026. Data for 3, 4 and 5 are from Yumoto et al. (2000). ND, Not detected. All these alkaliphiles were grown at $\mathrm{pH} 10$ and Bacillus subtilis was grown at neutral $\mathrm{pH}$.

\begin{tabular}{|c|c|c|c|c|c|}
\hline Fatty acids & 1 & 2 & 3 & 4 & 5 \\
\hline isoC $_{14: 0}$ & $2 \cdot 2$ & $1 \cdot 4$ & $2 \cdot 0$ & $0 \cdot 6$ & $1 \cdot 8$ \\
\hline $\mathrm{C}_{14: 0}$ & ND & ND & $0 \cdot 4$ & $0 \cdot 5$ & $0 \cdot 3$ \\
\hline isoC $_{15: 0}$ & $17 \cdot 1$ & $19 \cdot 2$ & $25 \cdot 9$ & $31 \cdot 8$ & $29 \cdot 1$ \\
\hline anteiso $_{15: 0}$ & $49 \cdot 0$ & $45 \cdot 6$ & $34 \cdot 6$ & $42 \cdot 9$ & $37 \cdot 9$ \\
\hline $\mathrm{C}_{15: 0}$ & $1 \cdot 1$ & ND & $0 \cdot 2$ & $0 \cdot 3$ & ND \\
\hline isoC $_{16: 0}$ & $0 \cdot 8$ & $1 \cdot 7$ & $5 \cdot 3$ & $1 \cdot 0$ & $4 \cdot 9$ \\
\hline isoC $_{16: 1}$ & $2 \cdot 1$ & $1 \cdot 3$ & $1 \cdot 3$ & $0 \cdot 2$ & $0 \cdot 1$ \\
\hline $\mathrm{C}_{16: 0}$ & $1 \cdot 6$ & $1 \cdot 6$ & $0 \cdot 9$ & $2 \cdot 1$ & $3 \cdot 2$ \\
\hline $\mathrm{C}_{16: 1}$ & $9 \cdot 8$ & $13 \cdot 6$ & $3 \cdot 1$ & $1 \cdot 5$ & $0 \cdot 2$ \\
\hline isoC $_{17: 0}$ & $2 \cdot 9$ & $3 \cdot 3$ & $4 \cdot 4$ & $4 \cdot 3$ & $11 \cdot 2$ \\
\hline anteiso $_{17: 0}$ & $4 \cdot 9$ & $4 \cdot 5$ & $10 \cdot 0$ & $11 \cdot 2$ & $9 \cdot 6$ \\
\hline isoC $_{17: 1}$ & $0 \cdot 7$ & $1 \cdot 1$ & $6 \cdot 9$ & $1 \cdot 7$ & $0 \cdot 3$ \\
\hline $\mathrm{C}_{17: 0}$ & $0 \cdot 2$ & ND & $0 \cdot 2$ & ND & $\mathrm{ND}$ \\
\hline anteiso $_{17: 1}$ & $4 \cdot 1$ & $4 \cdot 2$ & $4 \cdot 1$ & $0 \cdot 9$ & $0 \cdot 2$ \\
\hline $\mathrm{C}_{18: 0}$ & ND & ND & ND & ND & $0 \cdot 2$ \\
\hline $\mathrm{C}_{18: 1}$ & ND & ND & $0 \cdot 1$ & ND & ND \\
\hline Others & $3 \cdot 7$ & $2 \cdot 6$ & $0 \cdot 7$ & $0 \cdot 4$ & $1 \cdot 1$ \\
\hline Total unsaturated & $16 \cdot 7$ & $20 \cdot 2$ & $15 \cdot 5$ & $4 \cdot 3$ & $0 \cdot 8$ \\
\hline Iso-branched & $25 \cdot 8$ & $28 \cdot 0$ & $45 \cdot 8$ & $39 \cdot 6$ & $47 \cdot 4$ \\
\hline Anteiso-branched & $58 \cdot 0$ & $54 \cdot 3$ & $48 \cdot 7$ & $55 \cdot 0$ & $47 \cdot 7$ \\
\hline Ratio anteiso : iso & $2 \cdot 25$ & $1 \cdot 94$ & $1 \cdot 06$ & $1 \cdot 39$ & $1 \cdot 01$ \\
\hline Total branched & $83 \cdot 8$ & $82 \cdot 3$ & $94 \cdot 5$ & $94 \cdot 6$ & $95 \cdot 1$ \\
\hline
\end{tabular}

(1986) reported that obligate alkaliphilic Bacillus spp. contain a high concentration of unsaturated fatty acids. The isolates also contained a larger amount of unsaturated fatty acids than Bacillus subtilis, the faculatively alkaliphilic Bacillus cohnii and the obligately alkaliphilic Bacillus alcalophilus. The menaquinone and fatty acid contents of the new isolates are characteristic of the genus Bacillus.

The 16S rRNA gene sequence of strain $\mathrm{AM} 31 \mathrm{D}^{\mathrm{T}}$ was analysed to determine its phylogenetic position. The sequence of 1507 bases of the 16S rRNA gene of strain AM31D ${ }^{\mathrm{T}}$ was compared with those of 11 other alkaliphilic Bacillus and two neutrophilic or alkaliphilic species belonging to other related taxa. The phylogenetic tree constructed using the neighbour-joining method (Fig. 2) and 16S rRNA gene sequence similarity (data not shown) showed that strain $A M 31 D^{T}$ was a member of the Bacillaceae. Strain $\mathrm{AM} 1 \mathrm{D}^{\mathrm{T}}$ was placed in group 6 (alkaliphiles) (Nielsen et al., 1994). The highest similarity value was observed with the obligate alkaliphiles (Nielsen et al., 1995) Bacillus alcalophilus $(94 \cdot 7 \%)$ and Bacillus pseudalcaliphilus (94.8\%). These results and the demonstrated obligate alkaliphilic nature of $\mathrm{AM} 3 \mathrm{D}^{\mathrm{T}}$ were consistent with the phylogenetic placement of the isolates.
The DNA G + C contents of strains AM31D ${ }^{\mathrm{T}}$ and AM11D were 41.5 and $40.6 \mathrm{~mol} \%$, respectively. These values fell within the defined range of the genus Bacillus and were similar to those of the phylogenetically related alkaliphilic Bacillus species.

According to the results of the 16S rRNA gene sequence analysis, strain $\mathrm{AM} 31 \mathrm{D}^{\mathrm{T}}$ was closely related to Bacillus alcalophilus and Bacillus pseudalcaliphilus. Therefore, the level of DNA-DNA relatedness between strains AM31D ${ }^{\mathrm{T}}$ and $A M 11 D$, and the closely related strains given above were estimated. DNA-DNA relatedness results indicated that the two isolates were closely related to each other (more than $94 \cdot 7 \%$ similarity) and different $(9 \cdot 5-19 \cdot 3 \%$ similarity) from Bacillus alcalophilus and Bacillus pseudalcaliphilus (Table 2).

Bacillus strains AM31D ${ }^{\mathrm{T}}$ and AM11D differed from other relatively closely related species in terms of phenotypic characteristics as follows: Bacillus alcalophilus grows at $10{ }^{\circ} \mathrm{C}$, does not grow in $10 \% \mathrm{NaCl}$ and has a DNA G $+\mathrm{C}$ content of $36 \cdot 2-38 \cdot 4 \mathrm{~mol} \%$; Bacillus pseudalcaliphilus neither hydrolyses Tween 20 nor reduces nitrate, and grows at $10{ }^{\circ} \mathrm{C}$; Bacillus pseudofirmus dose not hydrolyse Tween 20 , deaminates phenylalanine and grows at $10{ }^{\circ} \mathrm{C}$; and Bacillus halodurans grows at $50^{\circ} \mathrm{C}$ (Table 3 ).

On the basis of the above results, the two isolates were designated as a new species for which name Bacillus krulwichiae sp. nov. is proposed; the type strain is $\mathrm{AM} 31 \mathrm{D}^{\mathrm{T}}$.

\section{Description of Bacillus kru/wichiae sp. nov.}

Bacillus krulwichiae (krul.wich.i'ae N.L. fem. gen. n. krulwichiae of Krulwich; named after American microbiologist Terry A. Krulwich who made fundamental contributions to the study of alkaliphilic bacteria).

Cells are Gram-positive peritrichously flagellated straight rods $(0 \cdot 5-0.7 \times 1.5-2.6 \mu \mathrm{m})$ and produce subterminally located ellipsoidal spores. Spores do not cause swelling of sporangia. Both aerobic and anaerobic growth is observed. Colonies are circular and colourless. Catalase and oxidase reactions are positive. Negative for indole production, ONPG hydrolysis and $\mathrm{H}_{2} \mathrm{~S}$ production. Growth occurs at $\mathrm{pH} 8-10$ at almost equal intensity, but not at $\mathrm{pH} 7$. Grows at $14 \% \mathrm{NaCl}$, but not at higher concentrations. Nitrate is reduced to nitrite. Acid, but no gas, is produced from D-xylose, D-glucose, D-fructose, D-galactose, D-ribose, maltose, sucrose, trehalose, glycerol and mannitol when grown at $\mathrm{pH} 10$. No acid is produced from D-arabinose, L-rhamnose, D-mannose, lactose, cellobiose, melibiose, raffinose, myo-inositol and sorbitol. Positive for hydrolysis of starch, DNA, hippurate and Tween 20, 40, 60 and 80. Hydrolysis of casein and gelatin is variable among strains. Utilizes benzoate and $m$-hydroxybenzoate as sole carbon sources. The major isoprenoid quinones are menaquinone-5, -6 and -7 . iso $_{15: 0}(17 \cdot 1-19 \cdot 2 \%)$ and anteiso $\mathrm{C}_{15: 0}(45 \cdot 6-49 \cdot 0 \%)$ represent the main fatty acids 


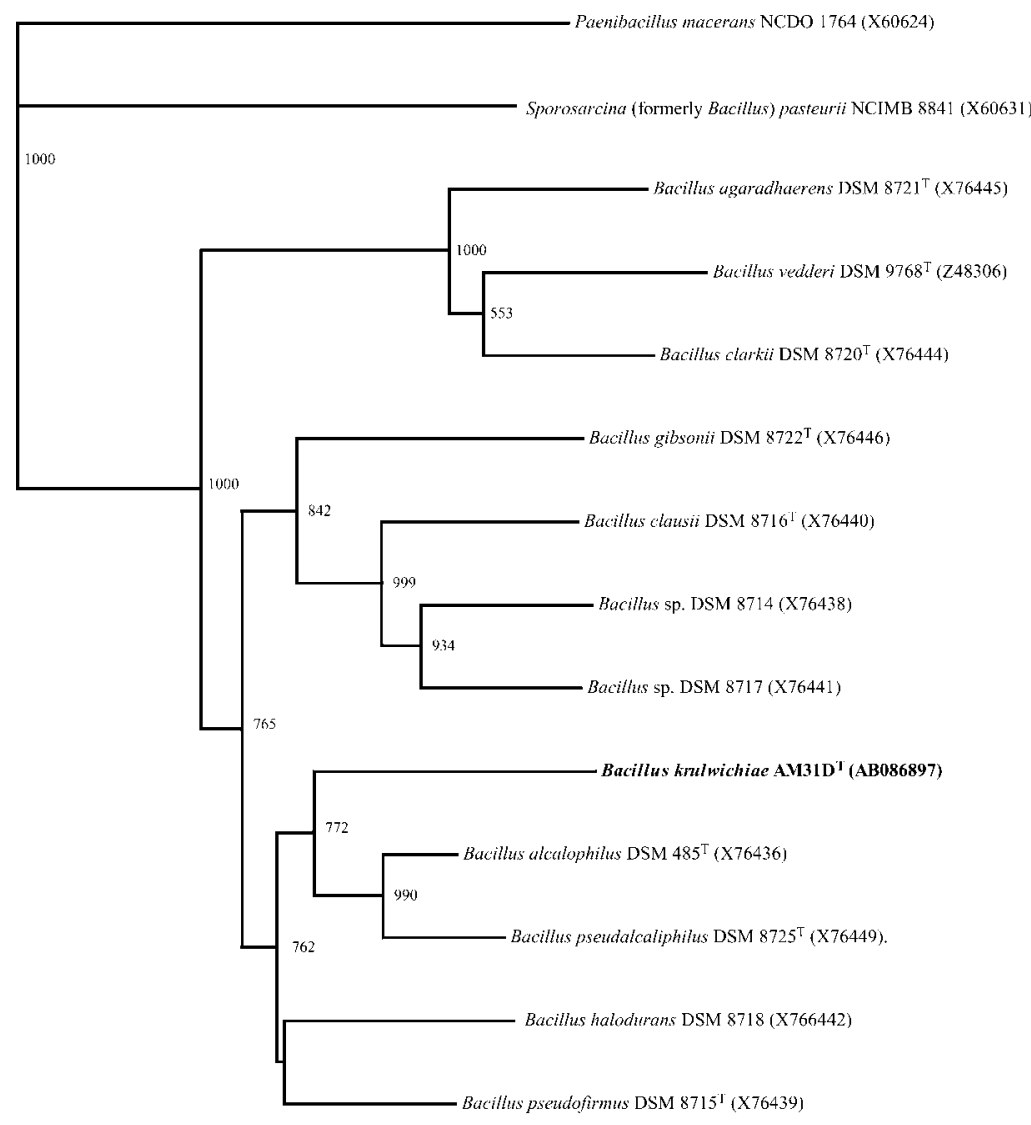

Fig. 2. Phylogenetic tree derived from 16S rRNA gene sequence data of Bacillus krulwichiae $\mathrm{AM}^{\mathrm{M}} 1 \mathrm{D}^{\top}$, other alkaliphilic Bacillus spp. and other related organisms using the neighbour-joining method. Numbers indicate bootstrap values greater than 500 . Bar, $0.01 K_{\text {nuc }}$ units.

produced during growth in an alkaline medium $(\mathrm{pH} \mathrm{10).}$ The DNA G $+\mathrm{C}$ content is $40 \cdot 6-41 \cdot 5 \mathrm{~mol} \%$, as determined by HPLC. Strains AM31D ${ }^{\mathrm{T}}$ and AM11D were isolated from a soil sample obtained from Tsukuba, Ibaraki, Japan.

Table 2. DNA base composition and levels of relatedness between Bacillus krulwichiae $\mathrm{AM} 1 \mathrm{D}^{\top}$ and $\mathrm{AM} 11 \mathrm{D}$ and DNAs of other closely related alkaliphilic Bacillus strains

\begin{tabular}{|c|c|c|c|}
\hline \multirow[t]{2}{*}{ Strain } & \multirow[t]{2}{*}{$\begin{array}{c}\mathrm{G}+\mathrm{C} \text { content } \\
(\mathrm{mol} \%)^{*}\end{array}$} & \multicolumn{2}{|c|}{$\begin{array}{c}\text { Reassociation }(\%) \\
\text { with biotinylated } \\
\text { DNA from: }\end{array}$} \\
\hline & & $\mathrm{AM} 1 \mathrm{D}^{\mathrm{T}}$ & AM11D \\
\hline $\begin{array}{l}\text { Bacillus krulwichiae } \\
\qquad \mathrm{AM} 1 \mathrm{D}^{\mathrm{T}}\end{array}$ & $41 \cdot 5$ & 100 & $96 \cdot 5$ \\
\hline $\begin{array}{l}\text { Bacillus krulwichiae } \\
\text { AM11D }\end{array}$ & $40 \cdot 6$ & $94 \cdot 7$ & 100 \\
\hline $\begin{array}{l}\text { Bacillus alcalophilus } \\
\text { JCM } 5262^{\mathrm{T}}\end{array}$ & $37 \cdot 3$ & $19 \cdot 3$ & $9 \cdot 5$ \\
\hline $\begin{array}{l}\text { Bacillus pseudalcaliphilus } \\
\text { DSM } 8725^{\mathrm{T}}\end{array}$ & $37 \cdot 9$ & $15 \cdot 1$ & $10 \cdot 4$ \\
\hline
\end{tabular}

${ }^{\star}$ Determined by HPLC.
Table 3. Characteristics differentiating Bacillus krulwichiae from other alkaliphilic Bacillus spp.

1, Bacillus krulwichiae; 2, Bacillus alcalophilus; 3, Bacillus pseudalcaliphilus; 4, Bacillus pseudofirmus; 5, Bacillus halodurans; 6, Bacillus clausii; 7, Bacillus gibsonii. +, Positive; v, variable among strains; - , negative. Characteristics of other alkaliphilic Bacillus spp. are from Nielsen et al. (1995).

\begin{tabular}{|c|c|c|c|c|c|c|c|}
\hline Characteristic & 1 & 2 & 3 & 4 & 5 & 6 & 7 \\
\hline \multicolumn{8}{|l|}{ Hydrolysis of: } \\
\hline Casein & $\mathrm{V}$ & + & + & + & + & + & + \\
\hline Gelatin & $\mathrm{V}$ & + & + & + & + & + & + \\
\hline Starch & + & + & + & + & + & + & - \\
\hline Tween 20 & + & $\mathrm{V}$ & - & - & $\mathrm{V}$ & - & - \\
\hline Tween 40 & + & + & $\mathrm{V}$ & + & + & - & $\mathrm{V}$ \\
\hline Tween 60 & + & + & $\mathrm{V}$ & + & + & - & $\mathrm{V}$ \\
\hline Deamination of phenylalanine & - & - & - & + & - & - & - \\
\hline Reduction of nitrate & + & $\mathrm{V}$ & - & - & $\mathrm{V}$ & + & $\mathrm{V}$ \\
\hline \multicolumn{8}{|l|}{ Growth at: } \\
\hline $10{ }^{\circ} \mathrm{C}$ & - & + & + & + & - & - & $\mathrm{V}$ \\
\hline $40^{\circ} \mathrm{C}$ & + & + & + & + & + & + & - \\
\hline $50{ }^{\circ} \mathrm{C}$ & - & - & - & - & + & + & - \\
\hline $\mathrm{pH} 7$ & - & - & - & $\mathrm{V}$ & $\mathrm{V}$ & + & + \\
\hline
\end{tabular}


Type strain is AM31D ${ }^{\mathrm{T}}\left(=\mathrm{NCIMB} 13904^{\mathrm{T}}=\mathrm{JCM} 11691^{\mathrm{T}}=\right.$ IAM $15000^{\mathrm{T}}$ ).

\section{References}

Agnew, M. D., Koval, S. F. \& Jarrell, K. F. (1995). Isolation and characterization of novel alkaliphiles from bauxite processing waste and description of Bacillus vedderi sp. nov., a new obligate alkaliphile. Syst Appl Microbiol 18, 221-230.

Aono, R. (1995). Assignment of facultative alkaliphilic Bacillus sp. strain C-125 to Bacillus lentus group 3. Int J Syst Bacteriol 45, 582-585.

Barrow, G. I. \& Feltham, R. K. A. (editors) (1993). Cowan and Steel's Manual for the Identification of Medical Bacteria, 3rd edn. Cambridge: Cambridge University Press.

Brosius, J., Palmer, J. L., Kennedy, P. J. \& Noller, H. F. (1978). Complete nucleotide sequence of $16 \mathrm{~S}$ ribosomal RNA gene from Escherichia coli. Proc Natl Acad Sci U S A 75, 4801-4805.

Clejan, S., Krulwich, T. A., Mondrus, K. R. \& Seto-Young, D. (1986). Membrane lipid composition of obligately and facultatively alkalophilic strains of Bacillus spp. J Bacteriol 168, 334-340.

Duckworth, A. W., Grant, W. D., Jones, B. E. \& Steenbergen, R. (1996). Phylogenetic diversity of soda lake alkaliphiles. FEMS Microbiol Lett 19, 181-191.

Ezaki, T., Hashimoto, Y. \& Yabuuchi, E. (1989). Fluorometric deoxyribonucleic acid-deoxyribonucleic acid hybridization in microdilution wells as an alternative to membrane filter hybridization in which radioisotopes are used to determine genetic relatedness among bacterial strains. Int J Syst Bacteriol 39, 224-229.

Fritze, D. (1996). Bacillus haloalkaliphilus sp. nov. Int J Syst Bacteriol 46, 98-101.

Gibson, D. T. \& Subramanian, V. (1984). Microbial degradation of aromatic hydrocarbons. In Microbial Degradation of Organic Compounds, pp. 181-252. Edited by D. T. Gibson. New York: Marcel Dekker.

Horikoshi, K. (1991). Microorganisms in Alkaline Environments. Weinheim: VCH.

Hugh, R. \& Leifson, E. (1953). The taxonomic significance of fermentative versus oxidative metabolism of carbohydrates by various Gram-negative bacteria. J Bacteriol 66, 24-26.

Kimura, M. (1980). A simple method for estimating evolutionary rates of base substitutions through comparative studies of nucleotide sequences. J Mol Evol 16, 111-120.

Krulwich, T. A. \& Guffanti, A. A. (1989). Alkalophilic bacteria. Annu Rev Microbiol 43, 435-463.

Marmur, J. (1961). A procedure for the isolation of deoxyribonucleic acid from micro-organisms. J Mol Biol 3, 208-218.
Mason, J. R. \& Cammack, R. (1992). The electron-transport proteins of hydroxylating bacterial dioxygenases. Annu Rev Microbiol 46, 277-305.

Nielsen, P., Rainey, F. A., Outtrup, H., Priest, F. G. \& Fritze, D. (1994). Comparative $16 \mathrm{~S}$ rDNA sequence analysis of some alkaliphilic bacilli and the establishment of a sixth rRNA group within the genus Bacillus. FEMS Microbiol Lett 117, 61-66.

Nielsen, P., Fritze, D. \& Priest, F. G. (1995). Phenetic diversity of alkaliphilic Bacillus strains: proposal for nine new species. Microbiology 141, 1745-1761.

Saitou, N. \& Nei, M. (1987). The neighbor-joining method: a new method for reconstructing phylogenetic trees. Mol Biol Evol 4, 406-425.

Spanka, R. \& Fritze, D. (1993). Bacillus cohnii sp. nov., a new obligately alkaliphilic, oval-spore-forming Bacillus species with ornithine and aspartic acid instead of diaminopimelic acid in the cell wall. Int J Syst Bacteriol 40, 92-97.

Switzer Blum, J., Burns Bindi, A., Buzzelli, J., Stolz, J. F. \& Oremland, R. S. (1998). Bacillus arsenicoselenatis sp. nov., and Bacillus selenitireducence, sp. nov. Two haloalkaliphiles from Mono Lake, California that respire oxyanions of selenium and arsenic. Arch Microbiol 171, 19-30.

Takami, H. \& Horikoshi, K. (1999). Reidentification of facultatively alkaliphilic Bacillus sp. C-125 to Bacillus halodurans. Biosci Biotechnol Biochem 63, 943-945.

Tamaoka, J. \& Komagata, K. (1984). Determination of DNA base composition by reversed-phase high-performance liquid chromatography. FEMS Microbiol Lett 25, 125-128.

Thompson, J. D., Higgins, D. G. \& Gibson, T. J. (1994). CLUSTAL W: improving the sensitivity of progressive multiple sequence alignment through sequence weighting, position-specific gap penalties and weight matrix choice. Nucleic Acids Res 22, 4673-4680.

Vedder, A. (1934). Bacillus alcalophilus n. sp.; benevens enkele ervaringen met sterk alcalische voedingbodems. Antonie Leeuwenhoek J Microbiol Serol 1, 143-147.

Yumoto, I., Yamazaki, K., Sawabe, T., Nakano, K., Kawasaki, K., Ezura, Y. \& Shinano, H. (1998). Bacillus horti sp. nov., a new Gramnegative alkaliphilic bacillus. Int J Syst Bacteriol 48, 565-571.

Yumoto, I., Yamazaki, K., Hishinuma, M., Nodasaka, Y., Inoue, N. \& Kawasaki, K. (2000). Identification of facultatively alkaliphilic Bacillus sp. strain YN-2000 and its fatty acid composition and cellsurface aspects depending on culture pH. Extremophiles 4, 285-290.

Yumoto, I., Yamazaki, K., Hishinuma, M., Nodasaka, Y., Suemori, A., Nakajima, K., Inoue, N. \& Kawasaki, K. (2001). Pseudomonas alcaliphila sp. nov., a novel facultatively psychrophilic alkaliphile isolated from seawater. Int J Syst Evol Microbiol 51, 349-355.

Yumoto, I., Nakamura, A., Iwata, H., Kojima, K., Kusumoto, K., Nodasaka, Y. \& Matsuyama, H. (2002). Dietzia psychraliphila sp. nov., a novel, facultatively psychrophilic alkaliphile that grows on hydrocarbons. Int J Syst Evol Microbiol 52, 85-90. 